\title{
As possibilidades de proteção ao trade dress ${ }^{1}$
}

\author{
The possibilities of protection to trade dress
}

\author{
ViníCIUS de Almeida XAVIER
}

\begin{abstract}
RESUMO
Diante do competitivo cenário concorrencial em que se encontram as empresas, é fundamental que o empresário utilize elementos gráfico-visuais, conhecidos como trade dress, como diferencial para atrair clientes e para se destacar em relação aos seus concorrentes. Esse conjunto-imagem agrega uma significação secundária à marca. A aplicação do trade dress pode se dar na embalagem, na forma do produto ou até mesmo no estabelecimento comercial. A problemática se encontra quando essa aparência visual se destaca como fator de sucesso e gerador de lucros para o empresário e chama a atenção dos imitadores que estabelecem um comércio parasita, pegando carona na identidade visual do titular. A legislação não contempla um dispositivo específico de proteção ao trade dress e, na maioria das vezes, o instituto é tratado em juízo à luz da repressão à concorrência desleal. Contudo, provar a concorrência fraudulenta não é tarefa fácil. Com o estudo apresentado neste trabalho, o empresário encontra meios acessíveis de proteção no Brasil, em especial no que diz respeito à aparência visual de produtos e à configuração arquitetônica de estabelecimentos comerciais, pelo intermédio das disposições constantes no Direito do Autor e da Propriedade Industrial.
\end{abstract}

Palavras-chave: Trade dress. Concorrência desleal. Propriedade intelectual. Marcas. Direito autoral. Propriedade industrial.

\begin{abstract}
Against the competitive landscape in which they are competitive companies, is essential that the business uses graphic elements-visual, known as trade dress, as a differential to attract customers and to stand out from its competitors. This set-image aggregates a secondary meaning to the trademark. The aplication of trade dress can occur with the packing process, in the formation of the product or in the commercial estabilishment. The problematic occurs when the visual appearance highlights like a factor of success and generating benefits to the businessman and draws attention to the imitators wich estabilish a paradise commercial, using their visual identity. The legislation does not include a specific device protection to trade dress and, most of the time, the institute is handled in court in the light of the repression of unfair competition. However, to prove fraudulent competition is no easy task. With the research presented in this study, the businessman find accessible means of protection in Brazil, in particular as regards the visual appearance of products and the architectural configuration of commercial establishments, by means of the provisions contained in the Law of Copyright and Industrial Property.
\end{abstract}

Keywords: Trade dress. Unfair competition. Intellectual property. Brands. Copyright. Industrial property.

\footnotetext{
a Advogado Sócio do Xavier Sociedade de Advogados. Graduado em Ciências Jurídicas e Sociais pela Faculdade de Direito da Pontifícia Universidade Católica do Rio Grande do Sul. E-mail: <vinixav@gmail.com>.
} 


\section{INTRODUÇÃO}

Para enfrentar um cenário concorrencial altamente competitivo e globalizado, é fundamental que o empresário busque a diferenciação como ferramenta essencial para se destacar em relação aos seus concorrentes. Diante dessa realidade, a busca pela preferência do consumidor faz com que as corporações adotem estratégias agressivas para se manterem competitivas exigindo ações que as diferenciem de seus concorrentes.

A marca empresarial, signo identificador da empresa, é dotada de valor e personalidade, capaz, inclusive, de em muitos casos representar o bem mais valioso da empresa. Contudo, ela por si só não possui força suficiente para posicionar uma empresa ou um produto no mercado. É preciso que junto à marca a empresa crie uma identidade visual capaz de trazer consigo um conceito suficiente que traduza os valores necessários para conquistar o consumidor ${ }^{2}$.

Essa identidade composta de elementos gráficovisuais de um produto ou mesmo de um estabelecimento deve despertar o interesse do consumidor. Não são raros os casos em que determinado produto ou serviço detenham uma distintividade perante os concorrentes graças a sua percepção visual. Dentre alguns casos de destaque, temos, como exemplos, a garrafa da Cocacola, a caneta Mont Blanc, o chocolate Toblerone, entre outros. Dessa forma é comum a identificação de determinado produto apenas pela roupagem de sua embalagem, tendo a marca, nesse caso, um destaque secundário. Isso também pode ocorrer com estabelecimentos comerciais, caracterizados por uma programação visual com tamanha personalidade que assegura ao consumidor sobre o local de qual se refere, como os estabelecimentos do McDonald's, Donuts, Pizza Hut, a título de exemplos notoriamente conhecidos $^{3}$.

$\mathrm{Na}$ busca pela distintividade no mercado, as empresas trabalham fortemente em ações no sentido de se estabelecer identificações visuais com o público em geral. $\mathrm{O}$ marketing se insere no desenvolvimento do projeto visual de embalagens, nas peças de merchandising e até mesmo na arquitetura corporativa, configurando o estabelecimento comercial. Atualmente não são raras as roupagens de produtos que influenciam na sua aquisição, tornando-se estimulantes do impulso aquisitivo ${ }^{4}$.

A esse conjunto visual que tem por função distinguir produtos e serviços, a doutrina da propriedade intelectual ${ }^{5}$ e o Poder Judiciário denominam como trade dress, ou também tratado sobre a denominação de conjunto-imagem.
Quanto mais destaque a identidade visual adquire no mercado, mais valor agrega à empresa, convertendo-se em geradora de uma potencial fonte de lucros. Todavia, essa identidade visual desperta a atenção de imitadores que objetivam se locupletar pela incorporação de elementos da impressão visual de produto ou serviço de outrem.

A proteção contra uso e reprodução não autorizada do trade dress não possui previsão legal específica no ordenamento jurídico pátrio, assim, ficando vulnerável a ações de imitadores e colocando sob apreciação dos julgadores a missão de subjetivamente decidir sobre os conflitos resultantes relacionados ao tema.

A análise do conjunto-imagem deve-se valer de uma apreciação extremamente criteriosa, pois é preciso traçar limites precisos entre a concorrência legítima e a fraudulenta. Desse modo, será assegurado, em casos específicos, o direito à livre concorrência garantido constitucionalmente. Não se pode resguardar casos de direitos exclusivos apenas com o intuito de propósitos anticompetitivos, desfavorecendo e restringindo assim a competitividade.

Diante dessa realidade, o objetivo deste trabalho é examinar um panorama do instituto e dos mecanismos legais de proteção existentes. Inicialmente, traçaremos as principais características que envolvem o signo distintivo (marca) da empresa. Em seguida, examinaremos a configuração e o conceito do instituto trade dress. Por fim, apresentaremos os mecanismos legais previstos na legislação brasileira para assegurar sua devida proteção jurídica, analisando suas diferentes formas de apresentação e como o Poder Judiciário está apreciando o tema, por intermédio de casos relevantes litigados e não deixando de apreciar casos estrangeiros para enriquecer ainda mais a matéria.

\section{NOÇÕES GERAIS SOBRE MARCAS}

Diante de um cenário cada vez mais competitivo, as empresas necessitam se diferenciar para identificar seus produtos e serviços. Apenas o nome empresarial não é suficientemente capaz de fixar na memória do consumidor determinada empresa. São necessários sinais e elementos figurativos com caráter identificadores para agir de forma a "marcar" na mente das pessoas a identificação de determinada empresa. Segundo Jack Trout e Steve Rivkin, influentes gurus do marketing:

A escolha entre diversas opções sempre se baseia nas diferenças, implícitas ou explícitas. Os psicólogos afirmam que as diferenças nitidamente evidenciadas, ancoradas no produto, conseguem acentuar a memorização, porque podem ser intelectualmente avaliadas ${ }^{6}$. 
Esse elemento com função de distinguir empresas denomina-se marca. De acordo com José Carlos Tinoco Soares, "a marca é o sinal pelo qual o produto ou serviço é conhecido e distinguido no mercado consumidor ou entre os usuários"7. O legislador brasileiro a definiu como sinais distintivos visualmente perceptíveis, não compreendidos nas proibições legais ${ }^{8}$. Já na lição de João da Gama Cerqueira, marca se conceitua como

todo sinal distintivo aposto facultativamente aos produtos e artigos das indústrias em geral para identificá-los e diferenciá-los de outros idênticos ou semelhantes de origem diversa9 .

Contudo, Carvalho de Mendonça não restringe apenas o caráter distintivo das marcas em sua definição, ele atribui ao conceito aspectos relacionados à qualidade, vejamos:

[...] consistem em sinais gráficos ou figurativos, destinados a individualizar os produtos de uma empresa industrial ou as mercadorias postas à venda em uma casa de negócio, dando a conhecer sua origem ou procedência, e atestando a atividade e o trabalho de que são resultado ${ }^{10}$.

Para Philip Kotler, com base no nome da marca, o usuário conhece que qualidades e características esperar do produto, assim como os serviços com os quais poderá contar ${ }^{11}$. A marca advém do intelecto humano, fomentado por fortes investimentos das empresas de marketing para que, pelo processo criativo, ela possa traduzir uma imagem corporativa forte capaz de seduzir e criar o desejo no público consumidor.

No Brasil, a Constituição Federal, em seu artigo $5^{\circ}$, XXIX, preceitua os direitos com relação ao tema:

A lei assegurará aos autores de inventos industriais privilégio temporário para sua utilização, bem como proteção às criações industriais, à propriedade das marcas, aos nomes de empresas e a outros signos distintivos, tendo em vista o interesse social e o desenvolvimento tecnológico e econômico do País [grifo nosso]. ${ }^{12}$

Apenas com a previsão constitucional, Denis Borges Barbosa alerta que seria um equívoco tratar sobre propriedade intelectual de forma global sem atentar para as especificidades e essências de cada uma das espécies ora em estudo. Nesse sentido, foram instituídas duas leis infraconstitucionais que visam regular as criações, quais sejam: Lei do Direito Autoral (Lei no 9.610/98) e a Lei da Propriedade Intelectual LPI (Lei no 9.279/96).
Na distinção dos diplomas, pela doutrina de Denis Borges Barbosa:

Se a criação é técnica, teremos uma hipótese de patente de invenção ou de modelo industrial. Se a criação é puramente estética, sem aplicação a produto industrial, poder-se-á ter a proteção pelo Direito Autoral; tendo-se uma obra de arte aplicada, com a qualificação de poder servir de tipo de fabricação industrial, estamos no domínio do desenho industrial ${ }^{13}$.

Marcas, segundo o Código da Propriedade Industrial (Lei no 9.279/96), são todos os sinais visualmente perceptíveis utilizados para distinguir, atestar conformidade ou caracterizar produtos ou, como descreve Ricardo Negrão:

Considerada em sua tríplice aplicação exposta no art. 123 do Código da Propriedade Industrial, marca é o sinal distintivo visualmente perceptível usado para distinguir produto ou serviço de outro idêntico, semelhante ou afim, de origem diversa, bem como para atestar a conformidade de um produto ou serviço com determinadas normas ou especificação técnicas e, ainda, para identificar produtos ou serviços provindos de membros de determinada entidade. ${ }^{14}$

$\mathrm{O}$ direito à marca está fundamentado no princípio atributivo $^{15}$, o qual sua propriedade é obtida pelo registro validamente expedido pelo Instituto Nacional da Propriedade Industrial (INPI). Com base no registro da marca são concedidos os poderes ao seu titular, equivalentes aos de propriedade.

$\mathrm{O}$ ordenamento jurídico assegura os direitos de personalidade à pessoa jurídica, conforme expresso no Código Civil Brasileiro em seu artigo 52: “Aplicase às pessoas jurídicas, no que couber, a proteção aos direitos da personalidade "16. A propósito, o respeitável Superior Tribunal de Justiça emitiu a súmula 227 que consolida a possibilidade de a empresa incorrer em dano moral ${ }^{17}$.

Conforme podemos constatar, a marca é dotada de direitos de propriedade, atribuindo ao seu possuidor ou criador legitimidade para usar e gozar de maneira que lhe for mais favorável, auferindo rendimentos de seus frutos.

\subsection{Bem intangível de grande valor}

A marca, antes mesmo de adquirir sua tutela jurídica e seu caráter patrimonial, era utilizada apenas como forma de um comerciante distinguir seu produto perante os concorrentes. Atualmente, ela segue com essa função primordial, mas agregada de muitas outras 
características, tornando o instituto mais complexo e com elevada importância.

Algumas empresas investem tanto em suas marcas que elas se tornam o maior bem da organização, como no caso da marca Coca-cola, que vale US\$ 83,8 bilhões ${ }^{18}$. No Brasil, um caso de sucesso é a marca Petrobras, que lidera como a mais valiosa, avaliada em US\$ 10,5 bilhões (R\$ 19,7 bilhões) ${ }^{19}$. Nota-se que é atribuída à marca uma valoração pecuniária, compondo $\mathrm{o}$ ativo das empresas. As organizações empresariais são compostas de ativos materiais e imateriais integrantes de seu estabelecimento comercial.

Apesar de a Lei no 9.279/96 dispor em seu art. $5^{\text {o }}$ que os direitos de propriedade industrial são considerados como bens móveis ${ }^{20}$, no entendimento de Ricardo Negrão, as marcas são classificadas como bens imateriais, integrantes do estabelecimento empresarial ${ }^{21}$. A definição da natureza jurídica da marca, em seu entendimento majoritário, segue no sentido para a caracterização como um direito de propriedade imaterial, por tratar-se de um bem incorpóreo, não sujeito, portanto, da proteção pelos interditos possessórios ${ }^{22}$.

Segundo doutrina João da Gama Cerqueira, "é um direito privado patrimonial, de natureza real, que tem por objeto bens ou coisas incorpóreas, tal como os outros direitos que compõem o quadro da propriedade imaterial"23. A jurisprudência do Superior Tribunal de Justiça ${ }^{24}$ corrobora nesse mesmo sentido quanto a natureza do instituto marcário.

Muitas empresas, atualmente, não podem sustentar sua vantagem competitiva no mercado global, cada vez mais competitivo, sem o uso de valiosos ativos intangíveis, como é o caso da produção intelectual ${ }^{25}$. É evidente a importância do ativo intangível como fator da geração de fundo de comércio.

\subsection{Espécies de marcas}

As marcas são classificadas levando em conta os elementos visuais que as compõem. Com base na apreciação quanto à forma do sinal distintivo, subsiste este aos elementos puramente nominativos ou verbais (caraterizados apenas por conterem palavras, nomes e expressões); quanto aos figurativos ou emblemáticos (aqueles que utilizam símbolos, figuras, sinais distintivos em geral); aos mistos, que são aqueles que combinam nominativos e emblemáticos; e, por último, a classificação quanto aos elementos tridimensionais, caracterizados pela sua forma física com caráter dotado de distintividade para identificar determinada empresa ou produto. As marcas ainda apresentam as espécies de produto ou serviço, coletivas e de certificação. Além de todas as apresentadas, elenca como espécies as marcas de alto renome e notoriamente conhecidas.

Quanto à registrabilidade da marca, a Lei de Propriedade Industrial ${ }^{26}$, em seu artigo 124, elenca uma lista taxativa de proibições que será importante para uma análise posterior neste trabalho, como é o exemplo das cores. Já o Código da Propriedade Industrial, ao caracterizar marca em seu artigo 122, afasta a possibilidade de ser registrados sinais que não sejam visuais ${ }^{27}$.

Para o presente trabalho importam as situações em que outras formas visuais possam assumir a função distintiva e atribuir o caráter identificador de determinada empresa ou produto, dada sua importância, por vezes incalculável.

\subsection{Significação secundária (secondary meaning)}

Em específicas situações, a identificação a determinado produto ou serviço não se dá pela marca, e sim por um conjunto de elementos visuais ou expressões que adquirem tamanha função diferenciadora que assumem a distintividade.

Conforme entendimento de Denis Borges Barbosa ${ }^{28}$, a respeito desse tema:

Mesmo quando uma palavra ou imagem é incapaz, a princípio, de ser distintiva, tal propriedade pode ser adquirida pelo fato de que seu uso ou a divulgação ocorra com tal intensidade ou por tanto tempo que o público tenha se habituado a associar o símbolo a uma origem de produtos ou serviços, mesmo em condições que vedariam seu registro por falta de distinguibilidade.

Essa configuração visual distintiva, pelo seu uso ou divulgação, denomina-se "significação secundária". Nesse contexto, surge o trade dress, ou conjunto-imagem, que tem sua significação relacionada na percepção visual, ou seja, como o produto ou serviço é apresentado ao público, compreendendo, assim, o aspecto visual da marca potencializando a sua imagem,fruto de um processo construtivo relacionado ao branding ${ }^{29}$.

Gilberto Strunck afirma ser fundamental para o sucesso das marcas que elas apresentem identidades visuais consistentes, que propiciem seu efeito acumulativo $^{30}$. Evidencia-se, dessa forma, uma aproximação muito forte entre o trade dress e a marca (trade mark) ${ }^{31}$. Especialistas chegam a abordá-lo como um tipo de marca. Contudo, o direito marcário nem sempre pode contemplar a proteção do conjunto-imagem.

Grande parte da doutrina apresenta o trade dress como um secondary meaning ou como sentido secundário: 
Em certos casos já se fixou o princípio de que o 'trade dress' seja inerentemente distintivo, e, por via de consequência protegível; noutros que só é protegível e/ou aceito como tal em juízo se cumprir o requisito e adquirir o 'sentido secundário"32.

Denis Borges Barbosa ainda ressalta que a eficácia distintiva do trade dress nasce da perspectiva psicológica do consumidor em relação a um produto e sua marca. Na perspectiva psicológica do consumidor, a eficácia distintiva e o significado secundário podem se fundir, mas há certa diferença técnica entre um e outro fenômeno ${ }^{33}$.

No entendimento de José Carlos Tinoco Soares, a atribuição do sentido secundário passa por minuciosa apreciação de elementos configuradores:

A aquisição do sentido secundário é uma questão de fato e uma grande variedade de provas é rotineiramente considerada pelas Cortes de Justiça para alicerçar as suas decisões. Dentre elas podem ser citadas: os valores e a natureza da publicidade em torno da marca em questão, o período de tempo em que a marca foi colocada no mercado, a quantidade de mercadorias vendidas e/ou de serviços prestados, o testemunho direto dos comerciantes, dos empregados e dos vendedores etc., e notadamente, o reconhecimento dessa evidência ${ }^{34}$.

No Brasil, como vimos, as marcas são de natureza atributiva e a propriedade é concedida ao titular com o regular registro na entidade competente (INPI). A significação secundária, mesmo que dotada de distintividade, por vezes não é aceita como registrável. Segundo manifestação do INPI, o secondary meaning somente teria aplicação nos países que adotam o sistema declaratório ${ }^{35}$.

O reconhecimento da significação secundária no direito internacional tem previsão em TRIPs - Acordo Sobre Aspectos dos Direitos de Propriedade Intelectual Relacionados ao Comércio ${ }^{36}$ :

15.1 Qualquer sinal, ou combinação de sinais, capaz de distinguir bens e serviços de um empreendimento daqueles de outro empreendimento, poderá constituir marca. Estes sinais, em particular palavras, inclusive nomes próprios, letras, numerais, elementos figurativos e combinação de cores, bem como qualquer combinação destes sinais, serão registráveis como marcas. Quando estes sinais não forem intrinsecamente capazes de distinguir bens e serviços pertinentes, os Membros poderão condicionar a possibilidade do registro ao caráter distintivo que tenham adquirido pelo seu uso. [...]
Como já visto, não existe competência do órgão registrador brasileiro para examinar a aquisição de distintividade extrínseca. Contudo, a jurisprudência se manifesta de forma favorável quanto ao tema:

APELAÇÃO CÍVEL N. 69.349 PROCESSO N. 94.02.18828-2 RELATOR: JUIZ ROGÉRIO VIEIRA DE CARVALHO. APELANTE: INSTITUTO NACIONAL DA PROPRIEDADE INDUSTRIAL - INPI. APELADO: VALLS \& CIA. LTDA. EMENTA: DIREITO ADMINISTRATIVO E PROCESSUAL CIVIL. PROPRIEDADE INDUSTRIAL. Nome de uso necessário, comum ou vulgar, sem relação com o serviço a distinguir, e revestido de suficiente forma distintiva, em razão do uso ininterrupto por quase duas décadas, não é alcançado pela irregistrabilidade do item 20 do art. 65 do Código da Propriedade Industrial. Procedência do pleito, em face do disposto no art. 6ํ, quinquies, da Convenção de Paris. Recurso a que se nega provimento. 'Sentença proferida contra autarquia federal não está sujeita ao duplo grau obrigatório de jurisdição'.

MARCA REGISTRADA. PALAVRA COMUM. ABSTENÇÃO DE USO. A Sociedade Brasileira de Cultura Inglesa, titular da marca, ajuizou ação ordinária para que a ré se abstenha de usar as palavras "cultura" ou 'cultura inglesa' de seu nome fantasia, qual seja, Cultura Internacional Ensino de Línguas. Assim, a Turma, por maioria, entendeu que não é lícito a ora recorrida usar a palavra 'cultura' em seu nome fantasia, pois ambas exploram o mesmo ramo do comércio e a autora é conhecida pelos estudantes como a 'cultura'. Logo, a reprodução parcial do nome de que é titular a autora afronta os arts. 189, I, e 195, V, da Lei no 9.279/1996. Condenou, ainda, a ré a abster-se de uso da marca 'cultura' bem como modificar o título do seu estabelecimento, substituindo o referido vocábulo por outro, sob pena de pagar multa diária no valor de mil reais, a partir de sessenta dias da intimação pessoal da parte e depois do trânsito em julgado da decisão ${ }^{37}$.

Para Patrícia Luciane de Carvalho, a característica distintiva pode explorar mais de um sentido: visão, audição, olfato, tato, gosto e gestual; os quais em conjunto transmitem ao mercado a percepção desejada pelo empresário ${ }^{38}$.

De tudo apresentado, o importante é analisar em profundidade o instituto trade dress, para que este obtenha o sentido secundário, sendo o elemento de diferenciação e destaque para o empresário. Assim, é necessário estabelecer um link entre o conjuntoimagem e a empresa ou produto,conforme abordaremos no capítulo seguinte. 


\section{TRADE DRESS OU CONJUNTO-IMAGEM}

A busca pela preferência do consumidor faz com que as corporações invistam em estratégias agressivas para se manterem competitivas, exigindo ações que as diferenciem de seus concorrentes.

A inovação e o pioneirismo são atributos que irão rotular a empresa bem planejada de forma a distinguila das demais. Jack Trout e Steve Rivkin, sobre o comportamento dos consumidores, afirmam que:

Para a mente do público, o fato de essas empresas terem sido pioneiras em suas categorias de produtos as tornam diferentes dos seus imitadores e elas adquiriram um status especial, por terem sido as primeiras a chegar ao topo da montanha ${ }^{39}$.

Como forma de sobrevivência em um mercado sempre exigente, a inovação passa a ser fator decisivo no sucesso de uma empresa, e o trade dress, ou conjunto-imagem, constitui-se em um grande aliado na busca da tão desejada distintividade no mundo dos negócios ${ }^{40}$.

O trade dress consiste na identidade visual corporativa e sua função está em expressar a imagem que a empresa quer representar para o mercado. Se uma empresa não possui uma boa imagem, ela causará uma má impressão, o que possivelmente refletirá nos resultados de seus rendimentos. David A. Aaker e Erich Joachimsthaler, em um de seus livros sobre posicionamento estratégico de marcas, lecionam que "a identidade visual da marca representa aquilo que a organização deseja que sua marca signifique"41.

$\mathrm{O}$ consumidor de hoje não separa o serviço ou produto da forma com a qual ele é exteriorizado. Segundo Patrícia Luciane de Carvalho, "o consumidor tem a forma de apresentação como parte integrante do serviço ou produto"

No entendimento de José Carlos Tinoco Soares, trade dress é conceituado da seguinte maneira:

O 'trade dress' representa o meio pelo qual um produto (em seu sentido mais amplo possível) é apresentado ao mercado. Dentre as inúmeras formas de aparição pode compreender a embalagem (qualquer que seja o tipo e/ou modelo), a configuração do produto, a cor e/ou combinação de cores que se apresenta, os métodos de comercialização, as maneiras de sua divulgação publicitária, o desenho e/ou estilização interna ou externa do estabelecimento (qualquer que seja), os pertences, partes e componentes de um produto ou se uma prestação de serviço ${ }^{43}$.
Em uma leitura mais extensiva, o douto autor descreve o trade dress com o seguinte significado associado como conjunto-imagem:

[...] a imagem total do negócio; num sentido bem geral, é o 'look and feel', isto é, o ver e o sentir do negócio; é o meio pelo qual o produto é apresentado ao mercado; é o identificador de origem; o termo 'trade dress' significa a imagem total ou a aparência geral de um produto ou serviço, incluindo, mas não limitado a, desenho da embalagem, rótulos, recipientes, mostruários, à característica do produto ou à combinação de elementos ou figuras que são ou se tornam associadas exclusivamente com uma existência particular que permitem funcionar como sendo um indicador de origem do produto; o 'trade dress' compreende uma única seleção de elementos que imediatamente estabelecem que o produto se distancia dos outros, por isso se torna inconfundível.

'Trade dress' e/ou conjunto-imagem, para nós, é a exteriorização do objeto, do produto ou de sua embalagem, é a maneira peculiar pela qual se apresenta e se torna conhecido. É pura e simplesmente a 'vestimenta', e/ou o 'uniforme', isto é, um traço peculiar, uma roupagem ou a maneira particular de alguma coisa se apresentar ao mercado consumidor ou diante dos usuários com habitualidade. Na generalidade da expressão 'alguma coisa' pode-se se incluir, mas, logicamente, não limitar às marcas figurativas ou mistas; tridimensionais; a todos os objetos que foram ou não sucetíveis de patentes, mas que se apresentam mediante uma forma de exteriorização característica; a toda e qualquer forma de produto ou de sua embalagem, desde que constituída de características particulares; a toda e qualquer decoração interna ou externa de estabelecimentos; a toda e qualquer publicidade desde que elaborada e apresentada com particularidades a torne conhecida como procedente de uma determinada origem.

Por todos esses e muitos outros elementos e componentes, o 'trade dress' nada mais é do que aquilo que já denominamos, desde há muito, ou seja, o 'conjunto-imagem' ${ }^{44}$.

Como fruto oriundo da capacidade intelectual e produto resultante da ciência do design, nada mais adequado que buscarmos uma definição dentro da referida área do conhecimento. Trade dress é, na verdade, na visão dos Designers, a identidade visual da marca,conforme podemos concluir na definição de Gilberto Strunck:

A identidade visual é o conjunto de elementos gráficos que irão formalizar a personalidade de um nome, ideia, produto ou serviço. Esses elementos agem mais ou menos como as roupas e as formas de as pessoas se comportarem ${ }^{45}$. 
$\mathrm{O}$ instituto do trade dress pode agregar enorme vantagem competitiva ao atribuir valor à empresa. Por essa razão, é considerado como um significante bem imaterial. Ele seria classificado por José L. Santos et al. como ativos intangíveis relacionados ao marketing, como aqueles usados na promoção de produtos e serviços ${ }^{46}$.

Não são raros os casos em que identificamos uma determinada empresa ou produto apenas pela aparência visual de seu estabelecimento ou embalagem, como ocorre, por exemplo, quando adentramos a qualquer loja da franquia McDonald's. A combinação de cores, móveis, elementos de decoração aliados à própria configuração operacional da loja não deixam dúvidas de qual estabelecimento se trata, sem a necessidade de identificarmos a marca distintiva ${ }^{47}$.

No caso das embalagens, Carlos Alberto Bittar Filho leciona em uma de suas obras:

Ao compor o produto, como sua roupagem definitiva para consumo, a embalagem exerce, dentre todas as criações referidas, a influência mais direta sobre o público em geral, representando verdadeiro elo de comunicação final entre produtor e consumidor. Também como integrante de sua ornamentação, a embalagem atua como força atrativa imediata do consumidor, impondo-lhe, muitas vezes, pela excitabilidade provocada, o impulso aquisitivo, para ele até imperceptível ou mesmo inevitável. É decisivo, no ato da compra, o fator psicológico, razão pela qual uma embalagem convidativa pode arrebatar o consumidor e adquirir a sua preferência, mantendo fiel a determinado produto. [...] Daí, a necessária proteção que devem merecer no campo jurídico, a fim de assegurarse a seu titular o uso pacífico e a garantir-lhe a competente reação, em caso de violações que venham a acontecer, na defesa dessas importantes peças do aviamento objetivo da empresa ${ }^{48}$.

O conjunto-imagem, ainda sem previsão específica para sua proteção, está presente nos mais variados ramos, tais como combustíveis, medicamentos, alimentos, cosméticos e até na padronização dos elementos de franquias.

\subsection{Origem}

No início, o trade dress compreendia apenas a aparência visual de rótulos e embalagens de produtos, entretanto, com o passar dos tempos, o conceito foi ampliado, acolhendo também a configuração de estabelecimentos comerciais.

A evolução do instituto começou a ter destaque no ano de 1992, com o julgamento pela Suprema Corte dos Estados Unidos do litígio envolvendo as empresas Two Pesos, Inc vs. Taco Cabana, Inc (no 91-971, June $26,1992)^{49}$. Na ocasião, a rede de lanchonetes de fast-food denominadaTaco Cabana promoveu uma ação para impedir o uso não autorizado da programação visual de seu negócio pela concorrente Two Pesos, atuante no mesmo nicho de mercado. Da decisão, a Corte entendeu que as características visuais daquele estabelecimento eram originais, the conferindo, assim, uma proteção especial à exclusividade de seu uso, referindo-se ao trade dress como "a imagem total do negócio" e não apenas suas características individualizadas separadamente.

A partir dessa decisão da justiça estadunidense, nos dizeres de José Carlos Tinoco Soares, se iniciou "a grande fase do efetivo combate aos atos de concorrência desleal sob a nomenclatura de trade dress" ${ }^{50}$.

Desde então, o instituto trade dress como o conjunto de características distintivas de um produto, serviço ou estabelecimento comercial se difundiu pelo mundo, sendo atualmente abordado por renomados doutrinadores de diversos países.

\subsection{Tratamento do instituto no Direito}

\subsubsection{Direito estrangeiro}

Com a globalização das relações comerciais, demandou a necessidade de uniformizar e regulamentar os direitos e limitações entre os detentores de direitos de propriedade intelectual de diversos países, razão pela qual diversos Tratados e Convenções Internacionais foram celebrados a respeito da matéria, tendo em muitos dos quais o Brasil como signatário.

A proteção ao trade dress pode-se atribuir basicamente pela aplicação, de forma isolada ou em conjunto, de leis que envolvem Direitos de Propriedade Intelectual (Direitos de Autor e Direitos de Propriedade Industrial), incluindo-se a repressão à concorrência desleal, que podem variar nos diferentes países.

No âmbito de diretrizes e princípios de proteção à propriedade intelectual, destacamos a Convenção da União de Paris, de 20 de março de 1883, da qual o Brasil figura como signatário. Destacamos seu primeiro artigo:

Art. 1

1 - Os Países a que se aplica a presente Convenção constituem-se em União para a proteção da propriedade industrial.

2 - A proteção da propriedade industrial tem por objeto as patentes de invenção, os modelos de utilidade, os desenhos ou modelos industriais, as marcas de serviço, o nome comercial e as indicações de procedência ou denominações de origem, bem como a repressão da concorrência desleal ${ }^{51}$. 
A previsão protetiva ao trade dress não se apresenta de forma explícita, contudo, dada a amplitude de proteção à propriedade intelectual apresentada na Convenção de Paris e nos demais Tratados e Convenções. A tutela se fundamenta na repressão ou combate à prática de concorrência desleal.

Sobre a repressão aos atos concorrenciais desonestos, leiamos o art. 10 para melhor exemplificar:

Art. 10 .

1 - Os países da União obrigam-se a assegurar aos nacionais dos países da União proteção efetiva contra a concorrência desleal.

2 - Constitui ato de concorrência desleal qualquer ato de concorrência contrário aos usos honestos em matéria industrial ou comercial.

3 - Deverão proibir-se especialmente:

1으odos os atos suscetíveis de, por qualquer meio, estabelecer confusão com o estabelecimento, os produtos ou a atividade industrial ou comercial de um concorrente.

$2^{\circ}$ As falsas afirmações no exercício do comércio, suscetíveis de desacreditar o estabelecimento, os produtos ou a atividade industrial ou comercial de um concorrente.

$3^{\circ}$ As indicações ou afirmações cuja utilização no exercício do comércio seja suscetível de induzir o público em erro sobre a natureza, modo de fabrico, características, possibilidades de utilização ou quantidade das mercadorias ${ }^{52}$.

Nos Estados Unidos, o trade dress tem amparo legal específico com o Lanham Act da Lei Federal de Marcas, que trata da proteção aos slogans, frases, embalagens de produtos e até a própria aparência do produto em si.

$\mathrm{Na}$ Itália, o instituto é abordado com base na repressão de concorrência desleal, observando a tentativa de confusão e desvio de clientela.

No Reino Unido, a proteção ao trade dress encontra amparo na Lei de Contrafração, a qual visa garantir a tutelar marcas não registradas.

$\mathrm{O}$ instituto trade dress encontra ainda amparo jurídico nos países como Suécia, África do Sul, Índia e Israel, neste último abordando a infração contra o conjunto-imagem no âmbito do "enriquecimento sem causa".

\subsubsection{Direito brasileiro}

$\mathrm{Na}$ legislação brasileira inexiste uma proteção específica ao trade dress, ou conjunto-imagem, principalmente pela ausência de qualquer dispositivo na Lei da Propriedade Intelectual e na Lei que trata sobre o Direito do Autor. Nosso sistema não reconhece a proteção exclusiva ao "conjunto-imagem", mas a apenas alguns elementos individualmente registráveis que compõem o agrupamento visual no todo.

Conforme Cecília Manara, ao Direito de Propriedade Intelectual foi reservada a tarefa de regular as relações concernentes às obras de natureza utilitária, envolvendo bens materiais de utilização empresarial, tendo por objeto as patentes de invenção, os modelos de utilidade, os desenhos ou modelos industriais e, ainda, as marcas de fábrica ou de comércio, as marcas de serviço, o nome comercial, os segredos industriais, bem como a repressão aos atos de concorrência desleal ${ }^{53}$.

Com relação ao Direito Autoral, ficou a responsabilidade de assegurar as relações jurídicas oriundas da criação e utilização de obras intelectuais voltadas à área da estética, da literatura, da arte e da ciência, obras que para serem objeto de tutela terão como exigência a originalidade.

Nesse contexto, cabe esclarecer que o instituto trade dress é a reunião de diversos bens de natureza intelectual, em que utilizados de forma conjunta adquirem distintividade, podendo pertencer tanto ao campo do Direito do Autor quanto ao Direito de Propriedade Intelectual ${ }^{54}$.

A ausência de previsão legal para proteção ao trade dress coloca a configuração visual de produtos e estabelecimentos à mercê de contrafatores, que poderão se valer de forma desautorizada desses elementos identificadores, obtendo ganhos econômicos. Não são raros no Brasil litígios que envolvem trade dress. O Judiciário Brasileiro diante da lacuna legal quanto à proteção ao instituto, na maioria dos casos apreciados, tem sua resolução com base na repressão à concorrência desleal ou, conforme o caso, de garantia à livre concorrência.

As embalagens de medicamentos estão entre as disputas mais intensas. Uma embalagem de remédio é composta não só da marca aplicada em seu invólucro, mas também de outros elementos distintivos e identificadores do próprio medicamento no mercado, como a combinação e disposição das cores, grafias e estilizações, tipografia e até mesmo o formato da embalagem. Essa aparência visual é fruto de investimento em processos criativos voltados a criar o "apelo visual" necessário para estimular o impulso aquisitivo. Isso é inegável.

Determinados elementos que compõem o trade dress não são passíveis de proteção, conforme vedação contida no art. 124, inc. VIII da Lei de Propriedade Industrial, em que não confere o registro às cores se aplicadas isoladamente ${ }^{55}$.

A Lei de Propriedade Industrial, norma esta que regula direitos e obrigações relativos às criações 
industriais, ampara os crimes contra propriedade industrial e os de concorrência desleal. Em consonância com a Convenção de Paris, a Lei no 9.279/96 (LPI), em seu art. 195, descreve a conduta de concorrência desleal como criminosa ${ }^{56}$.

A respeito das hipóteses de concorrência fraudulenta, Cecília Manara inclui ao ilícito a prática de atos confusórios que induzem o consumidor ao erro, sendo o objeto da fraude o próprio produto ou serviço colidente posto no mercado ${ }^{57}$.

Segundo Darrás (apud Eduardo Pimenta e Rui Caldas Pimenta), a concorrência desleal constitui "todo acto de mala fé practicado para producir la confusión de los productos de los fabricantes o comerciantes, o también para arrojar el descrédito sobre um estabelecimiento rival" 58.

Conforme José Carlos Tinoco Soares, a livre concorrência, como toda liberdade, não é irrestrita, o seu exercício encontra limites nos preceitos legais; excedidos esses limites, surge a concorrência desleal. Nos casos de concorrência desleal em que foi copiado o conjunto-imagem de determinado produto ou serviço (trade dress), a análise dos limites da usurpação da concorrência dependerão do conjunto probatório ${ }^{59}$.

Seguindo esse entendimento, o Supremo Tribunal Federal decidiu:

A livre concorrência, como toda liberdade, não é irrestrita; o seu exercício encontra limites nos preceitos legais que regulamentam e nos direitos dos outros concorrentes, pressupondo um exercício legal e honesto do direito próprio, expressivo da probidade profissional; excedidos esses limites, surge a concorrência desleal, que nenhum preceito legal define e nem poderia fazê-lo, tal a variedade de atos que podem constituí-los ${ }^{60}$.

A diferenciação entre a concorrência desleal e a livre concorrência está em um liame muito próximo, dessa maneira reiterando a necessidade de meios probatórios suficientes para que se caracterize o trade dress com a função distintiva ou definidora de um sentido secundário da marca.

A título de conhecimento, vejamos um julgado brasileiro, versando sobre o institutotrade dress.

AGRAVO DE INSTRUMENTO. RECONVENÇÃO EM AÇÃO DECLARATÓRIA COM PEDIDO DE TUTELA ANTECIPATÓRIA. PRODUTOS ALIMENTÍCIOS E IDENTIDADE MERCADOLÓGICA. LIVRE CONCORRÊNCIA E LIVRE INICIATIVA ECONÔMICA. INTERESSES/DIREITOS DIFUSOS CONSUMERISTAS. AUSÊNCIA DOS PRESSUPOSTOS À TUTELA ANTECIPATÓRIA PARA FINS
DE IMPEDIMENTO À UTILIZAÇÃO DE CONJUNTO-IMAGEM. O litígio acerca da similaridade entre conjuntos-imagens de produtos alimentícios não justifica a litis regulação enquanto inexistente qualquer elemento que confira embasamento à intromissão judicial na livre concorrência e na livre iniciativa econômica, mormente quando a hipótese revela que a controvérsia aloja-se ainda no plano da estrita estratégia de consolidação de identidade mercadológica dos referidos produtos. Reconhecimento da consolidação doutrinária e jurisprudencial da tutela inibitória (aplicável, precipuamente, em casos de concorrência), uma vez relacionado com o direito fundamental à tutela jurisdicional adequada e efetiva. Entretanto, in casu, mostram-se ausentes os pressupostos da aludida tutela, na modalidade antecipada. Inexistência de justificativa para ingerência judicial, em sede de cognição sumária, no sentido de impedir a utilização, por uma das empresas litigantes, do conjunto-imagem de produto alimentício, tendo como base apenas a suscitada similaridade. (Agravo de Instrumento no 70024007635 - TJ/RS).

A concessão de medidas liminares nessa área apresenta dificuldades, principalmente quando o litígio versa sobre a prática de concorrência desleal, pois a configuração do ato anticoncorrencial deriva de critérios bastante subjetivos.

Para concessão de tutela protetiva ao conjuntoimagem, por intermédio de sentença declaratória, alguns requisitos ${ }^{61}$ devem estar presentes, entre os quais:

a) O trade dress deve ser dotado de características bastante distintivas e peculiares (inerentes).

b) A possibilidade de confusão entre o trade dress do lesado e aquele utilizado pelo contrafator deve ser evidente.

Diante da importância que a identidade visual possui para o mercado e seu valor agregado ao patrimônio empresarial, são necessárias medidas protetivas mais eficazes para sua tutela, não podendo ficar a cargo do julgador um juízo subjetivo.

\section{PROTEÇÃO AO TRADE DRESS}

Constantemente surgem novas e agressivas estratégias para infringir os direitos de propriedade intelectual. A violação do trade dress, pela imitação do conjunto-imagem, é uma dessas artimanhas. A inadequação de medidas protetivas no ordenamento jurídico brasileiro faz com que isso potencialize o crescimento dessas infrações, assim colocando o consumidor em risco e afetando inclusive o 
desenvolvimento econômico do país. Para João da Gama Cerqueira, o contrafator sempre busca artifícios que encubram ou disfarcem o ato delituoso ${ }^{62}$. José Carlos Tinoco Soares adverte que basta que haja a possibilidade de indução ao erro ou confusão, quer seja pela reprodução integral, parcial, quer pela imitação do desenho industrial registrado, o crime de concorrência desleal se realiza e se consuma ${ }^{63}$.

A decisão sobre a possibilidade ou não de confusão permanece na esteira do juízo subjetivo, e sobre tal, o Superior Tribunal de Justiça ${ }^{64}$ decidiu que na dúvida deve sempre favorecer àquele que possui a tutela do INPI.

Como visto, o trade dress compreende diversas formas de exteriorização, em determinados casos ultrapassando a limitação do visualmente perceptível. Entretanto, no Brasil, apenas é possível proteção do que está compreendido no campo da visão.Como em muitos casos, a identidade visual compreende nítida distintividade perante os concorrentes e não se enquadra nas hipóteses permissivas de adquirir a registrabilidade pelo caráter atributivo. Nesse sentido, defende-se que qualquer elemento de distintibilidade é passível, ao menos, de proteção frente à concorrência desleal, independentemente de registro ${ }^{65}$. De nada adianta criar e fortalecer uma identidade visual própria se, no futuro, não se puder impedir a ação de usurpadores. A repressão contra atos de imitação pode se dar mediante a aplicação de diversas disposições do nosso ordenamento.

A própria Carta Constituinte de 1988 já assegura as garantias do empresário, estabelecidas em seu artigo $5^{\circ}$, inciso XXIX:

A lei assegurará aos autores de inventos industriais privilégio temporário para sua utilização, bem como proteção às criações industriais, à propriedade das marcas, aos nomes de empresas e a outros signos distintivos, tendo em vista o interesse social e o desenvolvimento tecnológico e econômico do País [grifos nossos] $]^{66}$.

Como o conjunto-imagem possui a característica de distinguir determinado produto ou serviço dos seus competidores, nota-se que é perfeitamente aceitável incluí-lo na categoria dos "outros signos distintivos" destacada pelo dispositivo. É fundamental a mínima exteriorização para se comprovar a prática dos verbos dos crimes contra as marcas de concorrência desleal ${ }^{67}$, neste último, aplicável aos casos sem registro na entidade reguladora (INPI).

A maior controvérsia gira em torno da matéria probatória, em produzir prova de confusão do mercado consumidor. Esse elemento é presumível, subjetivo e depende da concepção mediana do consumidor e daqueles que direta ou indiretamente estejam vinculados à causa (parte, juiz, perito e assistente pericial ${ }^{68}$. Dessa forma, para se determinar maior segurança jurídica e mais eficiente prestação jurisdicional, recomendam-se medidas protetivas objetivas para a realização da adequada tutela ao trade dress.

Com base nas legislações infraconstitucionais, a proteção ao trade dress está amparada pelas regras de repressão à concorrência desleal, assim como dos institutos da infração de marca, da infração de desenho industrial e da infração de direitos autorais. Contudo, antes de adentrarmos nos mecanismos legais de proteção existentes ao trade dress, é importante destacar a possibilidade de que determinada empresa invada espaço jurídico de terceiro sem violar um direito de propriedade intelectual diretamente. Essa é a posição do Supremo Tribunal Federal brasileiro que, em notável julgado do início da década de 1970, assim entendeu:

Procura-se no âmbito da concorrência desleal combater os atos de concorrência fraudulenta ou desonesta, que atentam contra o que se tem como correto ou normal no mundo dos negócios, ainda que não infrinjam diretamente patentes ou sinais distintivos registrados ${ }^{69}$.

A compreensão, nessas hipóteses, é de que o trade dress seja um signo usualmente utilizado por várias empresas e, dessa forma, não pode ser objeto de direitos de exclusividade ${ }^{70}$. Abordaremos no próximo tópico o que consiste esse conjunto-imagem utilizado em massa pelos concorrentes de um mesmo seguimento.

\subsection{Trade dress de uso generalizado}

Em determinados casos, o trade dress não está sujeito à proteção. Tal fato decorre porque o conjuntoimagem não foi protegido por uma negligência do titular ou pelo fato de o objeto ter um título de propriedade intelectual expirado, dessa forma integrando os bens de domínio público. Nesses casos, a reprodução do objeto por concorrentes não só é lícita como é prócompetitiva, já que permite a exploração do bem por diversas empresas, o que pode ser benéfico para o consumidor, notadamente em termos de preço $\mathrm{o}^{71}$.

Ponto fundamental está em determinar se apenas alguns elementos do trade dress são de uso comum ou se isso abrange o conjunto-imagem no todo. A título de exemplo, temos o mercado de tinturas para cabelos, em que quase todas as embalagens dos produtos desse segmento possuem fotos de modelos com cores de cabelos semelhantes aos dos concorrentes. Seria inviável para esse mercado exigir aparência visual 
diferente, pois, nesse caso, a embalagem auxilia o consumidor a visualizar o resultado que pretende com determinada coloração capilar.

Quanto à tendência de mercado com relação a determinados elementos, em uma análise comparativa entre as instituições financeiras constata-se que a cor azul está presente em grande parte das identidades visuais das marcas.

Na seara do trade dress, os limites residem também na impossibilidade de se obter proteção sobre métodos comerciais, conceitos, temas, elementos funcionais ou meras técnicas de marketing e de venda ${ }^{72}$.

Torna-se indispensável que o empresário adote atitudes agressivas em relação à proteção do seu trade dress desde o lançamento. Ao contrário, outros conjuntos-imagens semelhantes pegarão "carona" por concorrentes.

\subsection{Proteção com base no direito marcário}

No Brasil, a lei dispõe que é passível de registro como marca todo signo distintivo visualmente perceptível, excetuando os impedimentos legais. Baseado nesse entendimento, caso o trade dress caracterize-se pela distintividade e identificação do produto ou serviço do empresário (em sentido lato sensu), nada obsta a registrabilidade como marca mista ou tridimensional perante o Instituto Nacional da Propriedade Industrial (INPI).

Conforme já abordado neste trabalho, o Brasil adota o sistema atributivo de direitos, isso quer dizer que o título de propriedade sobre signos distintivos advém do regular registro, e não do simples uso, típico de países que adotam o sistema declaratório. Torna-se incontestável que o registro do trade dress como marca potencializa a posição do empresário como titular de direitos, pois lhe auferem importantes prerrogativas legais e processuais. O titular do registro de marca pode licenciar e alienar o conjunto-visual, assim como se basear nos dispositivos relativos à infração de marca para combater eventuais imitações.

O trade dress com relação ao Direito Marcário pode se dar com o registro na forma de marca mista ou tridimensional. Para José Carlos Tinoco Soares, marca mista compreende etiqueta, rótulo, envólucro, invólucro, embalagem e toda e qualquer forma de apresentação do artigo, produto ou mercadoria ao consumo. ${ }^{73}$ Quanto à marca tridimensional, consiste naquela constituída pela forma plástica do produto ou da embalagem, cuja forma tenha capacidade distintiva em si mesma e esteja dissociada do efeito técnico.

A partir do registro, ao titular é conferido direitos exclusivos em todo o território brasileiro, afastando assim eventuais defesas do infrator no sentido da ausência de relação concorrencial pelo fato de os competidores atuarem em diferentes estados da federação. Com a existência do registro da marca, há meios mais seguros para obtenção de liminares. Influenciados pelas características do sistema atributivo, os juízes brasileiros ficam mais tranquilos em conceder tutelas liminares. É relevante destacar que os prazos de titularidade são prorrogáveis perenemente conforme a manifestação do possuidor da propriedade.

\subsection{Proteção com base no desenho industrial}

O conjunto-imagem, algumas vezes, pode se dar com base na forma plástica ornamental de um objeto. Nesse caso, sua proteção é prevista via registro de desenho industrial. Para ser registrável no Brasil, além de não estar inserido nas proibições legais, o desenho industrial não pode estar compreendido no estado da técnica (requisito da novidade) e possuir uma configuração visual distintiva em relação aos objetos preexistentes (requisito da originalidade).

Conforme definição de Newton Silveira:

A novidade de um modelo ou desenho pode consistir na composição do conjunto, mesmo que suas partes sejam conhecidas. Segundo Pouillet, tais criações quando não despertam nenhum sentimento estético, satisfazendo apenas ao gosto da moda, somente podem ser protegidas pela lei de desenhos e modelos, caso contrário entram no domínio da propriedade artística $^{74}$.

O registro do trade dress como desenho industrial demonstra-se uma proteção de certo modo relevante, pois em relação aos prazos do INPI, se comparado ao registro de marca, o registro de desenho industrial é concedido em um lapso de tempo inferior.

Questão controversa diz respeito à cumulação de proteções. A dúvida centra na possibilidade da mesma configuração ornamental de um produto ser objeto de registro de desenho industrial e de registro de marca tridimensional simultaneamente. Para a doutrina, a proteção cumulativa é possível, pois o artigo 124, inciso XXII, da Lei de Propriedade Industrial determina que "não são registráveis como marca: XXII - objeto que estiver protegido por registro de desenho industrial de terceiro". Esse entendimento vem sendo acolhido pelo INPI, embora haja algumas discussões sobre o tema.

O empresário deve levar em consideração especialmente os prazos de proteção outorgados pelos institutos. Enquanto que o registro de desenho industrial é temporário, o registro de marca poderá ser prorrogado ilimitadamente. O cuidado que se deve ter está na hipótese de o empresário optar pelo registro de desenho industrial, em que o objeto, a princí- 
pio, decairia em domínio público após a expiração do título.

\subsection{Proteção com base no direito autoral}

Em determinados casos, a proteção ao trade dress também pode se atribuir via direito autoral, porque muitos dos seus elementos se inserem na definição de obra intelectual tutelada como uma criação de espírito $^{75}$. A título de exemplos, temos o caso de obras e projetos arquitetônicos, websites, bem como gravuras e desenhos aplicados a determinados produtos.

Os projetos arquitetônicos, na legislação brasileira, estão protegidos a partir da Lei de Direitos Autorais (Lei $\mathrm{n}^{\mathrm{o}}$ 9.610/98), em que em seu art. $7^{\circ}$, inciso $\mathrm{X}$, dispõe expressamente:

Art. $7^{\circ}$ São obras intelectuais protegidas as criações do espírito, expressas por qualquer meio ou fixadas em qualquer suporte, tangível ou intangível, conhecido ou que se invente no futuro, tais como: $[\ldots]$

$\mathrm{X}$ - os projetos, esboços e obras plásticas concernentes à geografia, engenharia, topografia, arquitetura, paisagismo, cenografia e ciência.

Não são raros os litígios judiciais que envolvem o comércio parasitário de identidade visual de estabelecimentos comerciais. Nota-se a construção jurisprudencial nacional:

[...] O punctum saliens da questão gira em torno do fato das rés estarem fabricando e comercializando peças de vestuário e calçados sob marca similar às que a autora fabrica e vende, sem sua autorização, além de conferir aos seus estabelecimentos aparência interna e externa muito semelhante à criada pela autora, além de adotar como marca a expressão MR. FOOT que é bem parecida com a marca da autora MR. CAT, gerando confusão nos consumidores, situação que configura concorrência desleal e desvio de clientela. [...]

Destarte em havendo semelhança tal, ao ponto das rés levarem à confusão alguns consumidores, ao ponto da marca 'Mr. Foot' ser tida com a marca 'Mr. Cat', torna-se irrefragável a imitação em detrimento da autora, suscetível, mesmo, de coibição e a ensejadora de reparação indenizatória pelos prejuízos comerciais advindos.

Assim, no que tange à imitação, imperioso consignar o seu conceito à luz do entendimento de JOSÉ CARLOS TINOCO SOARES, em sua obra intitulada Lei de Patentes, Marcas e Direitos Conexos, p. 201, Editora Revista dos Tribunais. Di-lo: 'A imitação consiste no artifício empregado na composição de uma marca, cuja finalidade é iludir a justiça e o consumidor desatento...'.
Evidente que, uma vez imitada uma marca, obviamente gerará confusão sobre a qual se está contraindo, induzindo o consumidor a adquirir uma mercadoria pensando ser outra, em típica atitude de concorrência desleal. Neste tópico, esclareceu o experto que “.... A loja 'mister' que estiver mais próxima do cliente é a loja que vai vender, porque os produtos são muito parecidos. Ao entrar numa dessas lojas o cliente somente saberá em qual delas está se prestar bastante atenção, verá que os vendedores das lojas Mr. Cat usam aventais azuis. Ou se observarem atentamente o nome das lojas em suas fachadas, que são extremamente parecidas." (fl. 246).

Assim, o trabalho pericial concluiu que, em face da grande semelhança que as marcas em comento guardam entre si, confunde os consumidores, que, desatentos, adquirirão, por certo, mercadorias vendidas pelas rés, quando, na verdade, quereriam adquirir as mercadorias comercializadas pela autora, causando-lhe, assim, flagrante prejuízo ${ }^{76}$.

Determinados ramos de mercado - como o de restaurantes e franchising, por exemplo -, a identidade visual do estabelecimento é elemento de extrema relevância da atividade empresarial e pode atribuir enorme vantagem competitiva do empresário em relação aos seus concorrentes.

A legislação brasileira assegura ao empresário lesado o direito de haver perdas e danos por atos tendentes a criar confusão entre estabelecimento comercial:

Art. 209. Fica ressalvado ao prejudicado o direito de haver perdas e danos em ressarcimento de prejuízos causados por atos de violação de direitos de propriedade industrial e atos de concorrência desleal não previstos nesta Lei, tendentes a prejudicar a reputação ou os negócios alheios, a criar confusão entre estabelecimentos comerciais, industriais ou prestadores de serviço, ou entre os produtos e serviços postos no comércio [grifos nossos $]^{77}$.

Com relação à aparência visual de websites, desenhos e gravuras, a proteção via direito de autor também mostra-se adequada, tendo em vista que, em seu artigo 7ํㅡㄹ inciso XIII, a lei concede proteção a qualquer obra que, por sua seleção, organização ou disposição de seu conteúdo, seja fruto de uma produção intelectual ${ }^{78}$.

No tocar das cores, elas compreendem elementos de extrema significância no trade dress, pois na maioria das vezes exercem grande importância na composição gráfico-visual dos produtos. Por essa razão, as cores são 
uma relevante questão a ser considerada nas disputas em torno do conjunto-imagem. Cumpre ressaltar que cores são passíveis de proteção se dispostas ou combinadas de modo peculiar e distintivo. A permissão de tutela, nesse caso, se fundamenta, pois muitas combinações de cores de fato são distintivas e absolutamente capazes de distinguir e identificar determinados produtos dos seus concorrentes no mercado.

Não obstante, quando se tem uma obra de arte justaposta a um desenho ou modelo industrial, o autor pode invocar ambas as proteções ${ }^{79}$.

Aspecto nebuloso está no não visível, pois o Brasil não oferece proteção às marcas sonoras, por exemplo, a não ser que a letra ou vinheta esteja depositada na Biblioteca Nacional ${ }^{80}$. Acontece que a vinheta pode ser dotada de distintividade para identificar determinado produto e/ou empresa. Temos como exemplos de vinhetas distintivas o "plin-plin" da Rede Globo, o qual é identificado mesmo sem estarmos assistindo à $\mathrm{TV}$, pois ao escutarmos sabemos de qual canal se trata.

A particularidade do mecanismo de proteção via direito autoral está no fato de ele não depender de registro, conforme o artigo 18 da Lei de Direitos Autorais.

Em relação ao trade dress, em alguns casos a imitação decorre de fraudadores de segmento diferente ao da empresa, ou seja, de não competidores do mesmo mercado. Em alguns casos, pode o empresário entender que a reprodução não autorizada afetaria o valor agregado a sua identidade visual, além de violar seu direito de autor sobre o trade dress do produto. Nesse caso não estaríamos diante de uma incidência de concorrência desleal, mas, sim, de violação ao direito do autor.

\section{CONSIDERAÇÕES FINAIS}

$\mathrm{Na}$ alta competitividade do mercado atual, é fundamental o empresário investir em um conjunto de elementos visualmente perceptíveis para chamar a atenção do consumidor e se distinguir dos concorrentes.

A embalagem, o produto e até mesmo o estabelecimento comercial podem ter sua aparência visual diferenciada e atrativa, agregando, dessa forma, uma vantagem competitiva frente aos seus competidores.

Abordar concorrência é discorrer sobre iniciativa privada e o princípio da liberdade aplicado à economia, desde que não se viole o direito alheio. A relação do trade dress com o produto, na maioria das vezes, estabelece-se de modo tão automático e intrínseco que é impossível desassociar um do outro. Nesses casos, o simples contato visual do trade dress é suficiente para associá-lo a determinado produto, sendo totalmente irrelevante a existência da marca nominativa no respectivo rótulo ou embalagem para a determinação de aquisição por parte do consumidor.

No Brasil, para que seja possível obter direitos exclusivos sobre determinado trade dress, cabe ao titular demonstrar a distintividade da configuração visual e a possibilidade de confusão ou uma associação indevida entre a identidade visual dos produtos ou serviços. Embora haja ausência de previsão legal específica para tratar sobre o instituto trade dress, o fato é que titulares dessas identidades visuais, quando impedidos de registros com base nas Leis do Autor ou da Propriedade Industrial, poderão ainda se valer da repressão à concorrência desleal, diga-se de passagem, a forma mais usual nos casos levados a juízo.

Concluímos assim que o empresário encontra meios acessíveis de proteção no Brasil, em especial no que diz respeito à aparência visual de produtos e à configuração arquitetônica de estabelecimentos comerciais. Quando possível o registro, o titular exerce seus direitos de forma objetiva sem a necessidade de um conteúdo probatório suficiente a fim de comprovar a confusão e a distintividade.

\section{REFERÊNCIAS}

AAKER, David A.; JOACHIMSTHALER, Erich. Como construir marcas líderes. Porto Alegre: Bookman, 2007.

ANDRADE, Gustavo Piva de. O trade dress e a proteção da identidade visual de produtos e serviços. Revista da ABPI, Rio de Janeiro, n. 112, maio-jun. 2011.

AUDY, Jorge Luis Nicolas. A interação Universidade-Empresa na área de TI e a Gestão da Propriedade Intelectual: O caso do Parque Tecnológico da PUCRS (Tecnopuc). In: Propriedade intelectual: o caminho para o desenvolvimento. São Paulo: Microsoft Brasil, 2005.

BARBOSA, Denis Borges. Uma introdução à propriedade intelectual. 2. ed. Rio de Janeiro: Lumen Juris, 2003.

BARBOSA, Denis Borges. O fator semiológico na construção do signo marcário. Rio de Janeiro: UERJ, 2006. Tese (Doutorado em Direito) - Faculdade de Direito, Universidade do Estado do Rio de Janeiro, 2006.

BARBOSA, Denis Borges. Revistando o tema da significação secundária. 2011. Disponível em: <http://www.denisbarbosa.addr. com/arquivos/200/propriedade/trade_dress.pdf $>$. Acesso em: 20 mar. 2012.

BITTAR FILHO, Carlos Alberto. Tutela dos direitos da personalidade e dos direitos autorais nas atividades empresariais. 2. ed. São Paulo: Editora Revista dos Tribunais, 2002.

BITTAR FILHO, Carlos Alberto. A concorrência desleal e a confusão entre produtos. Revista dos Tribunais, 2003. v. 550.

BRASIL. Constituição da República Federativa do Brasil de 1988. Disponível em: <http://www.planalto.gov.br/ccivil_03/ Constituicao/Constitui\%C3\%A7ao.htm>. Acesso em: 30 abr. 2012. BRASIL. Código Civil Brasileiro. Disponível em: <http://www. planalto.gov.br/ccivil_03/leis/2002/110406.htm>. Acesso em: 30 abr. 2012. 
BRASIL. Convenção da União de Paris para Proteção da Propriedade Industrial, de 20 de março de 1883, promulgada no Brasil pela DAI - Divisão de Atos Internacionais. Decreto n. 75.572, de 8 de Abril de 1975. Disponível em: <http://www.inpi. gov.br/menu-esquerdo/patente/pasta_legislacao/convencao paris html>. Acesso em: 8 mar. 2012.

BRASIL. Instituto Nacional de Propriedade Industrial - INPI. Disponível em: <http://www.inpi.gov.br>. Acesso em: 21 abr. 2011.

BRASIL. Lei n. 9.279, de 14 de maio de 1996. Regula direitos e obrigações relativos à propriedade intelectual. In: Diário Oficial da União, Brasília, 15 maio 1996.

BRASIL. Superior Tribunal de Justiça. REsp 899.839/RJ, Rel. Ministro MASSAMI UYEDA, terceira turma, julgado em 17 ago. 2010, DJe, 1 out. 2010.

BRASIL. Superior Tribunal de Justiça. Súmula n. 227: A pessoa jurídica pode sofrer dano moral. 08/09/1999 - DJ 20.10.1999.

BRASIL. Superior Tribunal de Justiça. REsp 1207952/AM, Rel. Ministro LUIS FELIPE SALOMÃO, 4a Turma, julgado em 23 ago. 2011, DJe 01/02/2012.

BRASIL. Superior Tribunal de Justiça. REsp 198.609-ES, Rel. Min. Barros Monteiro, julgado em 11 maio 2004.

BRASIL. Superior Tribunal de Justiça. RE 5.232 - $2^{\text {a }}$ Turma - DJ 11.10.1949, p. 3.262.

BRASIL. <http://epocanegocios.globo.com/Revista/Common/ 0, EMI160465-16363,00-O+QUE+E+TRADE+DRESS.html>. Acesso em: 12 maio 2012.

BRASIL. <http://solteagravata.com/2012/01/19/caso-louboutinvs-ys1\%E2\%80\%93-a-guerra-das-cores-na-u-s-court/>. Acesso em: 30 abr. 2012.

BRASIL. <http://www.conjur.com.br/2011-fev-09/tj-sp-naoaceita-tese-concorrencia-desleal-acao-bombril>. Acesso em $10 \mathrm{de}$ maio de 2012.

CARVALHO, Patrícia Luciane de. Trade dress: a proteção ao conjunto informativo do Banco Itaú S.A. Revista da ABPI, n. 114, 2011.

CERQUEIRA, João da Gama. Tratado de Direito Industrial, v. 2. Rio de Janeiro: Forense, 1946.

ESTADOS UNIDOS DA AMÉRICA. < http://newsandinsight. thomsonreuters.com/ uploadedFiles/Reuters_Content/2012/01_January/louboutinvysl--lawprofamicus.pdf> . Acesso em: $22 \overline{a b} \bar{r}$. 2012.

KOTLER, Philip. Marketing de A a Z. Rio de Janeiro: Elsevier, 2003.

LEVIGARD, Daniela de Almeida; SILVA, Nilson Ferreira. A proteção das marcas de alto renome no Brasil. Revista da ABPI, Rio de Janeiro, n. 86, jan.-fev. 2007.
MANARA, Cecília. A proteção jurídica do "trade dress" ou "conjunto-imagem". Propriedade Intelectual em perspectiva. Rio de Janeiro: Lúmen Juris, 2008.

MANZONI JR. Ralphe. As marcas mais valiosas do Brasil em 2012. Isto É dinheiro, n. 760, 27 abr. 2012. Disponível em: $<$ http:// www.istoedinheiro.com.br/noticias/82403 AS+MARCAS+MA IS+VALIOSAS+DO+BRASIL+EM+2012>. . Acesso em: 2 maio 2012.

MENDONÇA, Carvalho de. Tratado de direito comercial brasileiro. 5. ed. Rio de Janeiro: Freitas Bastos, 1955. v. V, parte I.

NEGRÃO, Ricardo. Manual de direito comercial e de empresa. 3. ed. São Paulo: Saraiva, 2003. v. 1.

PERRIER, Raymond. "Interbrand's World's Most Valuable Brands", relatório de junho de 1999, patrocinado pela Interbrand e pelo Citigroup, 1999.

PIMENTA, Eduardo; PIMENTA, Rui Caldas. Dos crimes contra a propriedade intelectual. São Paulo: Revista dos Tribunais, 2005. SANTOS, J. L. et al. Ativos intangíveis: fonte de vantagem competitiva. ConTexto, Porto Alegre, v. 6, n. 10, 2006.

SILVEIRA, Newton. A propriedade intelectual e a nova lei de propriedade industrial (Lei n. 9.279, de 14-5-1996). São Paulo: Saraiva, 1996.

SILVEIRA, Newton. Direito de autor no desenho industrial. São Paulo: Revista dos Tribunais, 1982.

SILVEIRA, Newton. Marcas: signo do empresário a título originário e a título derivado. Disponível em: $<$ http://www.newmarc.com.br/ novo/index.asp? p=artigos.asp>. Acesso em: 1 abr. 2011.

SOARES, José Carlos Tinoco. Tratado da propriedade intelectual: marcas e congêneres. São Paulo, Editora Jurídica Brasileira, 2003. v. 1.

SOARES, José Carlos Tinoco. "Concorrência desleal” vs. "trade dress" elou "conjunto-imagem”. São Paulo: Ed. do Autor, 2004. $368 \mathrm{p}$.

SOARES, José Carlos Tinoco. Tratado da propriedade industrial: patentes e seus sucedâneos. São Paulo: Jurídica Brasileira, 1998.

STRUNCK, Gilberto. Como criar identidades visuais para marcas de sucesso:um guia sobre o marketing das marcas e como representar graficamente seus valores. Rio de Janeiro, Rio Books, 2001.

TEIXEIRA, Cassiano Ricardo Golos. “Trade Dress”. Curitiba: Faculdades Integradas, 2005. Monografia (Direito da Propriedade Intelectual) - Faculdade de Direito.

TROUT, Jack; RIVKIN, Steve (Col.). Diferenciar ou morrer. Tradução de Eduardo Lassere. São Paulo: Futura, 2000.

VIEIRA, Simone de Freitas. A proteção jurídica do "trade dress" na Justiça. Valor Econômico, 29 set. 2006, Legislação \& Tributos.

\section{NOTAS}

${ }^{1}$ Artigo extraído do Trabalho de Conclusão de Curso apresentado como requisito parcial para obtenção do grau de Bacharel em Ciências Jurídicas e Sociais da Faculdade de Direito da Pontifícia Universidade Católica do Rio Grande do Sul, aprovado, com grau máximo, pela banca examinadora, composta pelos professores Fernando Smith Fabris (orientador), Adelia Green Koff e Fabiano Menke, em 4 de julho de 2012.

2 ANDRADE, Gustavo Piva de. O trade dress e a proteção da identidade visual de produtos e serviços. Revista da ABPI, Rio de Janeiro, n. 112, p. 1, maio-jun. 2011.

3 VIEIRA, Simone de Freitas. A proteção jurídica do 'trade dress' na Justiça. Valor Econômico. São Paulo, 29 set. 2006. Legislação \& Tributos, p. 2.

${ }^{4}$ ANDRADE, Gustavo Piva de. O trade dress e a proteção da identidade visual de produtos e serviços. Revista da ABPI, Rio de Janeiro, n. 112, p. 1, maio-jun. 2011.
${ }^{5}$ Esse aspecto será norteado, neste trabalho, por Tinoco Soares, Denis Barbosa, entre outros Doutos escritores.

${ }^{6}$ TROUT, Jack; RIVKIN, Steve. Diferenciar ou morrer. São Paulo: Futura, 2000, p. 24.

7 SOARES, José Carlos Tinoco. Tratado da propriedade industrial: marcas e congêneres. São Paulo: Editora Jurídica Brasileira, 2003, p. 116.

${ }^{8}$ BRASIL. Lei no 9.279, de 14 de maio de 1996. Regula direitos e obrigações relativos à propriedade intelectual. In: Diário Oficial da União, Brasília, DF, 15 maio 1996. Art. 122.

9 CERQUEIRA, João da Gama. Tratado da propriedade industrial. Rio de Janeiro: Edição Forense, 1946, p. 364.

${ }^{10}$ MENDONÇA, Carvalho de. Tratado de direito comercial brasileiro. 5. ed. Rio de Janeiro: Freitas Bastos, 1955, p. 215. v. V, parte I.

${ }^{11}$ KOTLER, Philip. Marketing de A a Z. Rio de Janeiro: Elsevier, 2003.

12 BRASIL. Constituição da República Federativa do Brasil de 1988. Disponível em: <http://www.planalto.gov.br/ccivil_03/Constituicao/ Constitui\%C3\%A7ao.htm>. Acesso em: 30 abr. 2012. 
${ }^{13}$ BARBOSA, Denis Borges. O fator semiológico na construção do signo marcário. Rio de Janeiro: UERJ, 2006. Tese (Doutorado em Direito) Faculdade de Direito, Universidade do Estado do Rio de Janeiro, 2006.

${ }^{14}$ NEGRÃO, Ricardo. Manual de direito comercial e de empresa. 3. ed. São Paulo: Saraiva, 2003, p. 142. v. 1.

${ }^{15}$ [...] II - O sistema jurídico pátrio adota o sistema atributivo, segundo o qual, somente com o registro da marca no Instituto Nacional da Propriedade Nacional é que se garante o direito de propriedade e de uso exclusivo ao seu titular, a não ser que se trate de marca notoriamente conhecida; [...] BRASIL. Superior Tribunal de Justiça. REsp 899.839/RJ, Rel. Ministro MASSAMI UYEDA, terceira turma, julgado em 17 ago. 2010, DJe, 1 out. 2010.

16 BRASIL. Código Civil brasileiro. Art. 52. Disponível em: <http://www. planalto.gov.br/ccivil 03/leis/2002/110406.htm>.Acesso em:30 abr. 2012.

17 BRASIL. Superior Tribunal de Justiça. Súmula n. 227: A pessoa jurídica pode sofrer dano moral. 08/09/1999 - DJ 20.10.1999

${ }_{18}$ PERRIER,Raymond. "Interbrand's World's Most Valuable Brands", relatório de junho de 1999, patrocinado pela Interbrand e pelo Citigroup, 1999.

19 MANZONI JR. Ralphe. As marcas mais valiosas do Brasil em 2012. Isto É dinheiro, n. 760, 27 abr. 2012. Disponível em: <http://www. istoedinheiro.com.br/noticias/82403_AS+MARCAS+MAIS+VALIOS AS+DO+BRASIL+EM+2012>. Acesso em: 2 maio 2012.

${ }^{20}$ BRASIL. Lei no 9.279, de 14 de maio de 1996. Regula direitos e obrigações relativos à propriedade intelectual. In: Diário Oficial da União, Brasília, 15 maio 1996. Art. 5o.

${ }^{21}$ NEGRÃO, Ricardo. Manual de direito comercial e de empresa. 3. ed. São Paulo: Saraiva, 2003, p. 142. v. 1.

${ }^{22}$ LEVIGARD, Daniela de Almeida; SILVA, Nilson Ferreira. A proteção das marcas de alto renome no Brasil. Revista da ABPI, Rio de Janeiro, n. 86 , p. 43 , jan.-fev. 2007.

${ }^{23}$ CERQUEIRA, João da Gama. Tratado da propriedade industrial. 2. ed. São Paulo: Revista dos Tribunais, 1982, p. 760. v. 2.

${ }^{24}$ BRASIL. Superior Tribunal de Justiça. REsp 1207952/AM, Rel. Ministro LUIS FELIPE SALOMÃO, QUARTA TURMA, julgado em 23/08/2011, DJe $01 / 02 / 2012$.

${ }^{25}$ SANTOS, J. L. et al. Ativos intangíveis: fonte de vantagem competitiva. ConTexto, Porto Alegre, v. 6, n. 10, 2ㅇ semestre 2006.

${ }^{26}$ BRASIL. Instituto Nacional de Propriedade Industrial - INPI. Disponível em: <http://www.inpi.gov.br>. Acesso em: 21 abr. 2011.

${ }^{27}$ BRASIL. Lei n. 9.279, de 14 de maio de 1996. Regula direitos e obrigações relativos à propriedade intelectual. In: Diário Oficial da União, Brasília, 15 maio 1996. Art. 122.

${ }^{28}$ BARBOSA, Denis Borges. O fator semiológico na construção do signo marcário. Rio de Janeiro: UERJ, 2006. Tese (Doutorado em Direito), Faculdade de Direito, Universidade do Estado do Rio de Janeiro, 2006.

29 Branding ou Brand management (em português, Gestão de Marcas) é um conjunto de imagens e ideias que representam determinada empresa. Fonte: $<$ http://pt. wikipedia.org/wiki/Branding\#cite note-1>. Acesso em: 12 maio 2012.

${ }^{30}$ STRUNCK, Gilberto. Como criar identidades visuais para marcas de sucesso:um guia sobre o marketing das marcas e como representar graficamente seus valores. Rio de Janeiro: Rio Books, 2001, p. 57.

${ }^{31}$ Nos Estados Unidos, o artigo § 43 (a), da Lei de Marcas (Lanham Act), confere mesmo tipo de proteção para trade dresses registrados ou não registrados, conforme já decidiu a própria Suprema Corte daquele país (Two Pesos, Inc. v. Taco Cabana, Inc. 505 U.S. 763, 1992).

32 SOARES, José Carlos Tinoco. "Concorrência desleal" vs. "trade dress" elou “conjunto-imagem”. São Paulo: Ed. do Autor, 2004, p. 97.

33 BARBOSA, Denis Borges. Revistando o tema da significação secundária. Disponível em: <http://www.denisbarbosa.addr.com/arquivos/200/ propriedade/trade dress.pdf $>$. 2011. Acesso em: 20 mar. 2012

34 SOARES, José Carlos Tinoco. "Concorrência desleal" vs. "trade dress" e/ou "conjunto-imagem". São Paulo: Ed. do Autor, 2004, p. 75.

${ }_{35}$ Edson Lobo, Procurador e Ex-Diretor de Marcas do INPI, mencionado por RICCI, Antonio Ferro, Secondary Meaning, Palestra no XXVI Seminário Nacional da Propriedade Intelectual, 2006, publicado nos Anais da ABPI.

${ }^{36}$ Esse acordo tem como objetivo estabelecer parâmetros mínimos para a proteção dos direitos de Propriedade Intelectual de forma que o comércio entre os membros da OMC, signatários do acordo, seja facilitado pelas garantias de proteção ao Direito de Propriedade Intelectual.

37 BRASIL. Superior Tribunal de Justiça. REsp 198.609-ES, Rel. Min. Barros Monteiro, julgado em 11 maio 2004.

${ }^{38}$ CARVALHO, Patrícia Luciane de. Trade dress: a proteção ao conjunto informativo do Banco Itaú S.A. Revista da ABPI, n. 114. 2011.
39 TROUT, Jack; RIVKIN, Steve. Diferenciar ou morrer. São Paulo: Futura, 2000, p. 94.

${ }^{40}$ MANARA, Cecília. A proteção jurídica do "trade dress" ou "conjuntoimagem". Propriedade Intelectual em perspectiva. Rio de Janeiro: Editora Lúmen Juris, 2008, p. 1.

${ }^{41}$ AAKER, David A.; JOACHIMSTHALER, Erich. Como construir marcas líderes. Porto Alegre: Bookman, 2007, p. 49.

${ }^{42}$ CARVALHO, Patrícia Luciane de. Trade dress: a proteção ao conjunto informativo do Banco Itaú S.A. Revista da ABPI, n. 114, 2011.

${ }^{43}$ SOARES, José Carlos Tinoco. "Concorrência desleal" vs. "Trade Dress" e/ou "Conjunto-Imagem". São Paulo: Ed. do Autor, 2004, p. 96-7.

44 SOARES, José Carlos Tinoco. "Concorrência desleal" vs. "Trade Dress" elou "Conjunto-Imagem". São Paulo: Ed. do Autor, 2004, p. 213.

${ }^{45}$ STRUNCK, Gilberto. Como criar identidades visuais para marcas de sucesso:um guia sobre o marketing das marcas e como representar graficamente seus valores. Rio de Janeiro: Rio Books, 2001, p. 57.

${ }^{46}$ SANTOS, J. L. et al. Ativos intangíveis: fonte de vantagem competitiva. ConTexto, Porto Alegre, v. 6, n. 10, 2006.

${ }^{47}$ MANARA, Cecília. A proteção jurídica do "trade dress" ou "conjuntoimagem". Propriedade Intelectual em perspectiva. Rio de Janeiro: Lúmen Juris, 2008, p. 3.

${ }^{48}$ BITTAR FILHO, Carlos Alberto. Tutela dos direitos da personalidade e dos direitos autorais nas atividades empresariais. 2. ed. São Paulo: Revista dos Tribunais, 2002, p. 159.

49 Two Pesos, Inc. vs. Taco Cabana, Inc., 505 U.S. 763 (1992).

${ }^{50}$ SOARES, José Carlos Tinoco. "Concorrência desleal" vs. "Trade Dress" e/ou "Conjunto-Imagem" São Paulo: Ed. do Autor, 2004.

${ }^{51}$ BRASIL. Convenção da União de Paris para Proteção da Propriedade Industrial, de 20 de março de 1883, promulgada no Brasil pela DAI - Divisão de Atos Internacionais. Decreto n. 75.572, de 8 de abril de 1975. Disponível em: <http://www.inpi.gov.br/menu-esquerdo/patente/ pasta legislacao/convencao paris html>. Acesso em: 8 mar. 2012.

52 BRAS̄IL. Convenção da União de Paris para Proteção da Propriedade Industrial, de 20 de março de 1883, promulgada no Brasil pela DAI - Divisão de Atos Internacionais. Decreto n. 75.572, de 8 de abril de 1975. Disponível em: <http://www.inpi.gov.br/menu-esquerdo/patente/ pasta_legislacao/convencao_paris_html>. Acesso em: 8 mar. 2012.

53 MANARA, Cecília. A proteção jurídica do "trade dress" ou "conjuntoimagem". Propriedade Intelectual em perspectiva. Rio de Janeiro: Lúmen Juris, 2008, p.

${ }^{54}$ MANARA, Cecília. A proteção jurídica do "Trade dress" ou "conjuntoimagem". Propriedade Intelectual em perspectiva. Rio de Janeiro: Lúmen Juris, 2008, p. 6.

${ }_{55}$ BRASIL. Lei n. 9.279, de 14 de maio de 1996. Regula direitos e obrigações relativos à propriedade intelectual. In: Diário Oficial da União, Brasília, 15 maio 1996.

${ }^{56}$ BRASIL. Lei n. 9.279, de 14 de maio de 1996. Regula direitos e obrigações relativos à propriedade intelectual. In: Diário Oficial da União, Brasília, 15 maio 1996.

${ }^{57}$ MANARA, Cecília. A proteção jurídica do "Trade dress" ou "conjuntoimagem". Propriedade Intelectual em perspectiva. Rio de Janeiro: Lúmen Juris, 2008, p. 6.

58 PIMENTA, Eduardo; PIMENTA, Rui Caldas. Dos crimes contra a propriedade intelectual. São Paulo: Revista dos Tribunais, 2005, p. 249 .

59 SOARES, José Carlos Tinoco. "Concorrência desleal" vs. "Trade Dress" elou "Conjunto-Imagem" São Paulo: Ed. do Autor, 2004, p. 9.

${ }^{60}$ BRASIL. Superior Tribunal de Justiça. RE 5.232 - 2 ${ }^{\mathrm{a}}$ Turma - DJ 11.10.1949, p. 3.262 .

${ }^{61}$ MANARA, Cecília. A proteção jurídica do "trade dress" ou "conjuntoimagem". Propriedade Intelectual em perspectiva. Rio de Janeiro: Lúmen Juris, 2008, p. 16.

${ }^{62}$ CERQUEIRA, João da Gama. Tratado de Direito Industrial, v. 2. Rio de Janeiro: Forense, 1946.

${ }^{63}$ SOARES, José Carlos Tinoco. Tratado da propriedade industrial: patentes e seus sucedâneos. São Paulo: Jurídica Brasileira, 1998.

${ }^{64}$ BRASIL. Superior Tribunal de Justiça.REsp 510.885/GO, Rel. Ministro CESAR ASFOR ROCHA, 4a Turma, julgado em 09/09/2003, DJ $17 / 11 / 2003$, p. 336

${ }^{65}$ CARVALHO, Patrícia Luciane de. Trade dress: a proteção ao conjunto informativo do Banco Itaú S.A. Revista da ABPI, n. 114, 2011.

${ }^{66}$ BRASIL. Constituição da República Federativa do Brasil de 1988. Disponível em: <http://www.planalto.gov.br/ccivil 03/Constituicao/ Constitui\%C3\%A7ao.htm>. Acesso em: 30 abr. 2012.

${ }^{67}$ CARVALHO, Patrícia Luciane de. Trade dress: a proteção ao conjunto informativo do Banco Itaú S.A. Revista da ABPI, n. 114, 2011. 
${ }^{68}$ CARVALHO, Patrícia Luciane de. Trade dress: a proteção ao conjunto informativo do Banco Itaú S.A. Revista da ABPI, n. 114, 2011.

${ }^{69}$ RTJ 56/447 - 1970.

${ }^{70}$ ANDRADE, Gustavo Piva de. O trade dress e a proteção da identidade visual de produtos e serviços. Revista da ABPI. Rio de Janeiro, n. 112, maio-jun. 2011, p. 17.

${ }^{71}$ Idem.

72 ANDRADE, Gustavo Piva de. O trade dress e a proteção da identidade visual de produtos e serviços. Revista da ABPI, Rio de Janeiro, n. 112, p. 20, maio-jun. 2011.

73 SOARES, José Carlos Tinoco. "Concorrência desleal" vs. "Trade Dress" e/ou "Conjunto-Imagem". São Paulo: Edição do Autor, 2004, p. 249.
74 SILVEIRA, Newton. Direito de autor no desenho industrial. São Paulo: Revista dos Tribunais, 1982, p. 65.

75 ANDRADE, Gustavo Piva de. O trade dress e a proteção da identidade visual de produtos e serviços. Revista da ABPI, Rio de Janeiro, n. 112, maio-jun. 2011, p. 22.

${ }^{76}$ Quarta Vara Cível de Goiânia. Autos n. 1101/97. Ação de Indenização, 17 de setembro de 2001 .

77 BRASIL. Código Civil Brasileiro. Disponível em: <http://www.planalto. gov.br/ccivil 03/leis/2002/110406.htm>. Acesso em: 30 abr. 2012.

78 Idem.

79 CERQUEIRA, João da Gama. Tratado da Propriedade Industrial. Rio de Janeiro: Edição Forense, 1946, p. 113.

${ }^{80}$ Fonte: <www.bn.br>.

Recebido em 30/04/2013; aceito em 29/04/2015. 